\title{
Viral political Campaign: Suppoters of Jokowi-Amin in Indonesia Presidential Election
}

\author{
Novita Damayanti ${ }^{1}$, Prasetya Yoga Santoso ${ }^{2}$, Radja Erland Hamzah ${ }^{3}$ \\ Faculty of Communication Science, University of Prof. Dr. Moestopo (Beragama) Jakarta, \\ Indonesia ${ }^{1,2,3}$ \\ \{novita.damayanti@dsn.moestopo.ac.id ${ }^{1}$,prasetyayoga@dsn.moestopo.ac.id², \\ radjaerland@dsn.moestopo.ac.id $\left.{ }^{3}\right\}$
}

\begin{abstract}
Social media is an effective political campaign because it can make messages viral. These message is easily reposted, shared, and commented on Facebook fanpage. Indonesia is in the third place on Facebook users with 130 million users. In the 2019 presidential election in Indonesia supporters of the candidates were required to be creative in using social media to win votes, supporters were part of the campaign. Facebook is used as media to distribute messages quickly, widely, and simultaneously, which is called "viral". This research uses constructivist perspective. It is qualitative research method with single case study. Supporters create political contens in social media that are viral in political campaign for Jokowi-Amin. Thus, it is representations of Jokowi-Amin's voters behavior through messages and opinions by the loyal supporters. The result is the media can be interaction between supporters of Jokowi-Amin in the form of comments and shares. Many of supporter spread jokowi-Amin's campaign posts to other social media platforms to get a lot of support. The viral Facebook invitations by supporter for GBK Event of JokowiAmin campaign reached all over Indonesia even to all elements of Indonesian society with only a week. It was a successful big event where more than 160 thousand volunteers and supporters came and enlivened the campaign on GBK.
\end{abstract}

Keywords: Political Campaign; Social Media; Viral; Political Communication; Election

\section{Introduction}

Facebook is one of the media to increase political support through social media. This medium is carried out by various parties such asvolunteers of Jokowi and both of the candidates to win Presidential Election. Presidential and vice-presidential candidates used social media as their campaign instruments during the 2019 Election campaign period.Joko Widodo-Ma'ruf Amin and Prabowo Subianto - Sandiaga Uno post on the timeline of Facebook, Instagram, Twitter, and YouTube. The tendency of campaign messages wasdifferent. Jokowi-Ma'ruf Amin as the first candidateuseFacebook, while PrabowoSandiaga as candidate number 2 prefer to use Instagram. This was stated at the Program 
Monitoring and Content of the Presidential Candidates in Mass and Social Media from The One World Community, on December 12, 2018, by Anwari Natari [1].

The One World Community is monitoring social media accounts of presidential, vice presidential and their teams during the 2019 election campaign period. Based on the data from social media users on the Websindo.com site in January 2019, Indonesia is the 3rd largest country in its social media usage especially Facebook for $81 \%$ of the total 150 million social media users in Indonesia. There are around 130 million Facebook users in Indonesia, which is a basic factor for Jokowi-Amin's suppoters to choose Facebook as one of its campaign mediums [2].

In the 2019 Presidential Election, both Prabowo and Jokowi clearly have a buzzer team to creating discourse and the formation of public opinion, counteracting or even producing nonstop black campaign material in cyberspace. There are war terms in digital public space at this time.Indonesia wasillustrated as a period of online soldiers and cyber soldiers were armed with Hoax news. Indonesians describe the current situation as an "emergency hoax".Social media easily triggers conflict because of the low level of literacy. Thus, many common people are easily provoked and believe it even though the source is not yet clear.

The strategy of social media such as Facebook is considered quite accurate in the formation of public opinion and representation of Jokowi-Amin. Viral issues become trending topics on the Facebook timeline. Supporters of Jokowi-Amin on Facebook are considered to have big impact on the public opinions. There was a lot of war of statements which made the political situation heated up at that time, for example Jokowi-Amin planned to invite participants to gather at GBK in the last round of campaign. There were unexpected numbers of supporters, even some media statedthat the number were beyond the number 2 campaign. GBK was actually "white" by Jokowi-Amin supporters (as they used white shirt). There were viral hash tagsand memes such as \#putihkanGBK \#BarengJokowi \#menangkan01. Thus, it urged the participants to come in the campaign.

In the middle of the widespread information on SARA, there is information on hoaxes during the 2019 presidential election campaign while there are also entertain and positive information such as the rise of humorous and positive entertaining information from the supporters of Jokowi - Amin. There are memes of supporton social media such as Facebook. Jokowi-Amin's supporters make humorous messages. Thus, the message content in social media becomes viral. Support for whitening GBK through Facebook forms the chance between supporters to attend and vote. Support of alumni associations and communities is viral from supporters'number 1 as collaboration between supporters of Jokowi - Amin in the 2019 Presidential Election.

Based on the phenomenon of the event, researchers realized that social media such as Facebook was able to be a medium for viral political campaigns in 2019 especially for the Jokowi-Amin. Viral is not limited to the distribution of information but also to personal feeling. It has reached the stage of formation of opinion and emotional, where supporters with an emotional comments through social media to gather and maintain the leaders they lead. Supporters in cyberspace (Facebook) shows that the flow of information on Facebook fluctuated according to the development of an event in real life. Various patterns of manifestations are made by the supporters to persuade netizens to join and expand the support movement through videos, news, songs, designed profiles (protest icons), ironic images, symbols, and memes [3].

This study aims to analyze the viral political campaign of the Jokowi-Amin through social media by supporters in Indonesian presidential election. The conceptual frameworks of this research are political communication, viral campaign, political impression, and social media. 
This study uses a constructivist perspective. It is qualitative research method with a single case study. Data, mainly findings from observations, in-depth interviews and documentation, were collected to identify various interesting forms of viral campaigns for the Indonesian presidential election in 2019 by the Jokowi-Amin's Supporter. it was also internet users in Indonesia who use social media as media for their support interaction. Supporters created a lot of meme for all audiences to join in the Jokowi-Amin campaign on social media which made this political campaign increasingly viral . Jokowi-Amin's loyal supporters will always give a positive message in shaping public opinion and good representation. This research focuses on the strategy of viral political campaign of the Jokowi-Amin through social media by supporters in the Indonesian presidential election in 2019. This study aims to analyze the viral political campaign of the Jokowi-Amin through social media by its supporters in the Indonesian presidential election in 2019.

\section{Methods}

This research is a qualitative study with a case study approach.Case studies are a comprehensive description and explanation of various aspects of an individual, a group, an organization (community), a program, or a social situation [4]. For this research, data were collected from interviews with main supporters which was categorized technically by analyzing contents of Facebook supporters and Jokowi-Amin's team. In addition, this research analyzes the messages on Facebook about Jokowi- Amin which are related to the white movement of GBK. These memes were considered to have certain meanings in order to construct a reality. These messages would be used as primary data. Last, textual analysis focused on searching and collecting texts, books, and other information about presidential election campaign in 2019 both viral campaigns and digital political communication.

\section{Results and Discussions}

\subsection{Political Communication in the Digital Era}

Media helped published the content to public. The media also will distribute it again to the public. At this level, there is a top-down process in political communication between candidate and communities because communication goes only through certain media channels. However, the public or voters are dissatisfied because social media is considered unable to create active political discussions such as direct discussions [5]. But in fact many political campaigns use social media as a medium for discussion, because social media is considered as an interactive media.

Social media has an influence in the political such as political communication especially in election campaigns [6][7][8]. Political communication is a process by languages and symbols used by leaders, media, citizens, or experts. It is undesirable effects on political cognition, attitudes, or individual behavior or on results that is borne by the political policies. Thus, the definition has a very comprehensive aspect [9].

It is important for political institutions to be able to actively participate in political communication based on social media especially in election campaigns. Social media is an ideal capitals and information base to identify public opinion about political policies and positions. In addition, it creates community support for politicians. Studies show that 
politicians in global context have adopted social media to establish relations with constituents, create direct dialogue with the public and form political discussions. Thus, social media is important for politicians to create a space for dialogue between politicians and the public and attract young voters [8].

The internet can be a potential way of breaking down the oppressive politics of mass democracy. It can be media to discuss voices from the bottom up. The authorities can use it to the benefit of the groups with their power. The internet is expected to be a medium for the flow of interactive two-way informations between politicians and supporters. The internet promises to provide the broadest forum for the development of groups and as a medium of opinions [10]. In Indonesia, internet begun since the 1997 Election. There were parties in the election such as Golongan Karya, the Indonesian Democratic Party, and the United Development Party. They created an official website asa medium of information such as party programs, political statements, central or regional management, regulations, and opportunities for dialogue with administrators. In the 2004 and 2009 elections, the internet increased for political parties, individual candidates for legislators, candidates for presidential and vice presidents [11]. In Indonesia, social media were used in the past ten years. Facebook was popular social media as a medium for distributing news that is more flexible to the public due to 150 million social media users in Indonesia and 130 million of them use Facebook. Thus, Facebook is considered appropriate to be used asmedium for the formation of public opinions in election campaigns in Indonesia.

\subsection{Social Media in Viral Political Campaigns}

Social media is an effective and efficient media of conveying information to public. Social media is dynamic to allow open communication in various parties with diverse backgrounds and it can educate awareness of citizen participation in constructionof the cities(Howard \& Parks, 2012).Social media is not separated from the mainstreamsocial media nowadays which are often used for political campaigns, such as Facebook, Twitter, Instagram, Youtube. It is also used in chat-based such as Whatsapp, Line, Kakao Talk, Telegram, etc. There are various types of media. The following data are an overview of the phenomenon of community behavior towards social media in Indonesia.The function of social media can be identified through Honeycomb framework. The relationship of the honeycomb as a framework defines social media by seven functional building blocks for example identity, conversations, sharing, presence, relationships, reputations, and groups [12].

The total user reaches 150 million users, this means the majority of the internet use to socialize through social media. Social media users reaches $56 \%$ of the total population of Indonesia. Mobile-based users are 130 million. Thus, no wonder all social media platforms have finally focused on optimizing their applications on mobile.

The most widely used social media in Indonesia is Youtube. Facebook is in the 3rd position and Twitter is in the 6th position.Viral is to describe something that is very quickly becoming popular among internet users by publishing or sending information to people [13]. Viral campaigns are political campaigns of digital technology to express a candidate's political goals [13]. Howard also stated that this form of campaign made it possible for people to exchange information and spread rapidly like a virus (viral). The viral political campaign is an integration of various elements, such as digital technology, organizational adaptation, communication objectives, political leadership of candidates, volunteers, financial contributors, society, and other political campaigns. Through this campaign, people can transmit messages quickly, interact with netizens, and filter out what data they want to 
consumedue to internet-based. The community is also able to access informations quickly compared to conventional campaign [14].Internet-based media are used as intermediaries to distribute messages on political viral campaigns such as electronic mail, social networking, blogs, chatrooms and forums [15].

\subsection{Digital Political Campaign in the 2019 Presidential Election}

Based on the description and review of social media through Facebookin Jokowi Amin's campaign, the results of the research are found as following description.During the 2019 Election campaign period, presidential and vice-presidential candidates used social media as their campaign media. Both the candidates, Joko Widodo-Ma'ruf Amin and Prabowo Subianto-Sandiaga Uno, often exposed on social media Facebook, Instagram, Twitter, and YouTube. The trend is that Jokowi-Ma'ruf Amin is campaigning more through Facebook, while Prabowo-Sandiaga uses Instagram more.

The main reason of Facebook as the social media for the campaign is due to the approximately 130 million Facebook users of 150 million internet users. Indonesia was also the third largest country that used social media. The selection of social media Facebook as a campaign medium is appropriate because society use it, the message sent is fairly fast and on target. There is a space of interaction in the form of likes, comments and shares. Thus, the wider community and the world are able to respond to emerging political issues with fast spatial time, and it is not limited to space and time both in Indonesia and in other parts of the world.

The comparisons of upload issues on the campaign were both 460 for Prabowo - Sandi and 382 for Jokowi - Amin. The Jokowi-Ma'ruf were monitored as not yet actively campaigning on social media during the period September to October 2018. However, as of November 2018, the candidates were more active. Until December 2018, Jokowi-Ma'ruf recorded a superior number in social media campaigns. In December, the Jokowi-Ma'ruf began to outperform. Prabowo-Sandi was active only during October and November. It was recorded that there were 16 accounts affiliated with the Jokowi-Ma'ruf and 18 affiliated accounts with Prabowo- Sandiaga. These accounts are registered with the KPU. The data is obtained from the website www.iklancapres.id it is explained that Jokowi-Amin use Facebook and Instagram as campaign media, while the number 2 candidate widely used Instagram and Twitter for political campaigns.

\subsection{Viral Political Campaign by Supporters of Jokowi - Amin Facebook Fanpage}

There were various forms of viral politics campaign of presidential election in 2019 . Supporters actually speak and give a political message content on fellow to provide support. It is not only in text but also action. Some activities that occur during the 2019 presidential election campaign were supported the GBK event jokowi- Amin campaign to share and invite all people to join and coming the Event. Many of supporter spread jokowi-Amin's campaign posts to other social media platforms to get a lot of support. The invitations to this campaign reached all over Indonesia even to all elements of Indonesian society with only a week.

Movement in GBK was one of the viral political campaigns of Jokowi's supporters. We know that the viral definitions by howard is to describe something that is very quickly becoming popular among internet users by publishing or sending information to people (Howard, 2006). We have The viral memes by volunteers and supporters from Jokowi-Amin FanpageFacebookto invite the public to attend the Jokowi-Amin campaign on GBK on April 
13, 2019. The enthusiasm of the community was very high because meme had already received 1,000 shares and likes in one hour. There were around 2.4 million comment in the meme (Facebook, 2019).

Viral campaigns are indeed very effective in the dissemination of information through social media. It is fast and accurate. Jokowi-Amin's campaign is able to fill the stadium. Volunteers from a variety of elements attended the summit opens campaign candidate Joko Widodo - Ma'ruf Amin in 2019. Based on CNNIndonesia.com, they wore white shirt with picture of Jokowi- Amin. In addition, coalition party attributes to volunteer groups were also put in various corners of the SUGBK area.

Grand campaign of Jokowi - Amin was held on April 13, 2019 as the closing campaign of the 2019 presidential election campaign activity before a quiet week of presidential election day. Concerted political campaigns were one form of political campaign where the success of this activity due to supporters simultaneously providing support through social media. The messages conveyed through Facebook were increasingly viral. It was the main agenda. The viral message is formalized forms a collaboration to unite supporters and volunteers.

\section{Conclusions}

In conclusion, viral political campaign of Jokowi-Amin that was constructed by volunteers and supporters on social media has brought positive influences. The power of social media is unlimited due to connectivity and it can influence audiences in any part of the world. There are cases of viral messages in social media that the researchers adopted in this study. It was a successful big event where more than 160 thousand volunteers and supporters came and enlivened the campaign on GBK. The campaign invitation on Facebook has been shared, commented on and liked by more than 1 million people and became viral on social media. It can be concluded that social media has played and will continue to play an important role in political campaigns in 2019. The prospect used of social media through platforms such as Facebook, Twitter and Youtube is a promising medium for political campaigns and political candidates. Public will continue to interact directly with their supporters without spatial and time boundaries.

\section{References}

[1] Kompas.com. (2018). Kampanye di Medsos, Jokowi-Ma'ruf Lebih Manfaatkan Facebook, Prabowo-Sandi Instagram. Retrieved July 21, 2019, from kompas.com website: $\quad$ https://nasional.kompas.com/read/2018/12/13/07021911/kampanye-dimedsos-jokowi-maruf-lebih-manfaatkan-facebook-prabowo-sandi.

[2] We are social. (2019). Indonesia Digital 2019. Retrieved July 22, 2019, from We are social website: https://websindo.com/indonesia-digital-2019-tinjauanumum/\%0Ahttps://datareportal.com/reports/digital-2019-indonesia

[3] Cao, W., Cheong, A., \& Li, Z. (2014). How Facebook Functions in a Social Movement: An Examination Using the Web Mining Approach. Asian Journal for Public Opinion Research, 1(4), 268-291. https://doi.org/10.15206/ajpor.2014.1.4.268

[4] Mulyana, D. (2008). Metode Penelitian Kualitatif: Paradigma Baru Illmu Komunikasi dan Ilmu Sosial Lainnya. Bandung: Remaja Rosdakarya. 
[5] Sern, T. J., \& Zanuddin, H. (2014). Malaysia's 13th General Election: Political Communication and Public Agenda in Social Media. Asian Journal for Public Opinion Research, 1(2), 73-89. https://doi.org/10.15206/ajpor.2014.1.2.073

[6] Chavez, J. (2012). \# Fail: The Misuse of Social Media in the 2012 US Presidential Campaign. Retrieved from https://www.tcd.ie/policyinstitute/assets/pdf/PL_Chavez_March12.pdf

[7] Riaz, S. (2010). Effects of New Media Technologies on Political Communication. Journal of Political Studies, 1(2), 161-173.

[8] Stieglitz, S., \& Dang-Xuan, L. (2013). Social media and political communication: a social media analytics framework. Social Network Analysis and Mining, 3(4), 1277 1291. https://doi.org/10.1007/s13278-012-0079-3

[9] Perloff, R. M. (2013). Political Communication: Politics, Press, and Public in America. In The International Encyclopedia of Communication. https://doi.org/10.1002/9781405186407.wbiecp053.pub2

[10] Asih, I. W. (2011). Proceding Seminar Nasional Demokrasi dan Masyarakat Madani. Media Sosial Dan Politik: Sarana E-Democracy Atau Sekadar Pepesan Kosong?, 471. Retrieved from http://www.pustaka.ut.ac.id/dev25/pdfprosiding2/fisip201131.pdf

[11] Putra, A. M. (2011). Media Baru dan Fenomena Komunikasi Politik pada Pemilukada di Provinsi Banten 2011. Jurnal ULTIMA Comm, 3(2), 23-34. https://doi.org/10.31937/ultimacomm.v3i2.203

[12] Kietzmann, J. H., Hermkens, K., McCarthy, I. P., \& Silvestre, B. S. (2011). Social media? Get serious! Understanding the functional building blocks of social media. Business Horizons, 54(3), 241-251. https://doi.org/10.1016/j.bushor.2011.01.005

[13] Howard, P. N. (2006). New Media Campaigns and the Managed Citizen. Retrieved from https://smpsebastiao.files.wordpress.com/2010/09/e-book_gcc_howard_nmcampains-and-managed-citizen.pdf

[14] Suryanto, N. K., \& Rusfian, E. Z. (2012). Kampanye Politik Viral Dan Proses AgendaBuilding Media Massa Online (Studi Pada Kampanye Politik Faisal-Biem Selama Masa Kampanye Pemilukada DKI Jakarta 2012). Retrieved from http://lib.ui.ac.id/naskahringkas/2015-08/S44172-Niken Kinanti Suryanto

[15] Burney, J. (2008). Tittle : Get Viral Get Visitors. Oklahoma: jb-publishing. 